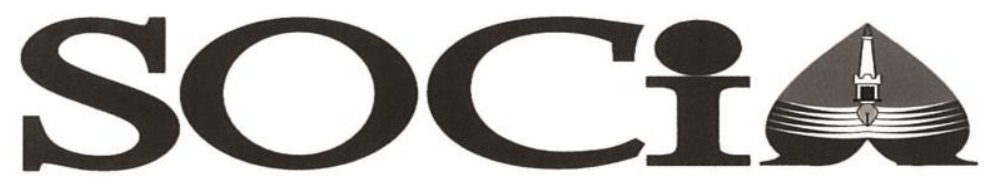

JU R N A L I L MU - I LMU SOS I A L

Juni 2016, Vol. 15, No. 1

\title{
Model Kebijakan Kombinasi dalam Perlindungan HAM Terhadap Narapidana di Lembaga Pemasyarakatan
}

\author{
SRI HARTINI, ANANG PRIYANTO, IFFAH NURHAYATI \\ Jurusan Pendidikan Kewarganegaraan dan Hukum FIS UNY \\ sri_hartini@uny.ac.id, anang_priyanto@uny.ac.id, iffah_nurhayati@uny.ac.id
}

\begin{abstract}
Abstrak
Penelitian ini bertujuan menggambarkan model kebijakan kombinasi perlindungan HAM terhadap narapidana di Lembaga Pemasyarakatan DIY. Penelitian ini merupakan penelitian deskriptif dengan pendekatan kualitatif. Subjek penelitian ditentukan secara purposive, pengumpulan data dengan wawancara dan dokumentasi diperkuat FGD, analisis data dengan analisis induktif. Hasil penelitian menunjukkan model kebijakan kombinasi perlindungan HAM terhadap Narapidana dapat digambarkan: 1) Mengatur "eksistensi" hak kebutuhan biologis narapidana dalam bentuk perubahan Undang-Undang; 2) Mengatur anggaran pengadaan obat-obatan bagi narapidana yang sakit sehingga pelayanan kesehatannya terpenuhi; 3) Mengatur anggaran melanjutkan keterampilan bagi narapidana; 4) Mengatur pengadaan SDM profesional bidang pendidikan, agama, kesehatan, psikologi, serta keterampilan. Teknis kebijakan dirancang dalam peraturan menteri dengan memperhatikan pertimbangan rasional, menekankan pada aspek efektivitas, efisiensi, dan ekonomis. Efektivitas pelaksanaan model kebijakan kombinasi tersebut belum terlaksana sehingga belum dapat diobservasi, disebabkan: sistem kewenangan sentralistik, uji coba model kebijakan kombinasi berimplikasi pada banyak aspek, narapidana jumlahnya besar, serta anggaran penyediaan fasilitas pendukung pelaksanaan dan lokasi uji coba kebijakan sangat bersifat politis.
\end{abstract}

Kata kunci: model kebijakan, HAM, narapidana

\begin{abstract}
This study aims to describe the combination of policy models protection of human rights of prisoners in Penitentiary DIY. This research is a descriptive qualitative approach. The subject of research is determined purposively, collecting data through interviews and FGD strengthened by documentation, data analysis with inductive analysis. The results showed a combination of protection of human rights policy model of Prisoners can be drawn: 1) Set the "existence" of biological needs of prisoners rights in the form of changes to the Act; 2) Set a budget for the procurement of medicines for sick prisoners so that health services are met; 3) Adjust the budget to continue the skills for prisoners; 4) Set the procurement of HR professionals in education, religion, health, psychology, as well as skills. Technical policies designed in a ministerial regulation with regard rational considerations, emphasizes the aspects of effectiveness, efficiency, and economical. The effectiveness of the implementation of the policy model of such combinations has not done so yet observable due to: a centralized authority system, the test model of policy combinations implicated in many aspects, large numbers of prisoners, as well as supporting the implementation of the budget provision of facilities and test sites highly political policy.
\end{abstract}

Keywords: model of policy, human rights, prisoners 


\section{PENDAHULUAN}

\section{Latar Belakang}

Dewasa ini masalah hak asasi manusia (HAM) semakin marak di Indonesia. Hal ini ditandai semakin meningkatnya tuntutan anggota masyarakat baik secara individu maupun kolektif terhadap penegakan HAM. Fenomena tersebut menunjukkan betapa besar perhatian masyarakat terhadap HAM, baik yang menyangkut pribadi maupun HAM secara kelompok. Berbicara masalah HAM dapat berkaitan dengan pelbagai dimensi kajian, antara lain berkaitan dengan konstelasi politik, ekonomi, hukum, sosial, dan budaya serta pertahanan dan keamanan, sehingga masalah HAM sebenarnya menyangkut berbagai segi kehidupan dalam berbangsa dan bernegara.

Masalah HAM sesungguhnya bukanlah merupakan masalah baru sebagaimana istilah HAM yang baru dikenal setelah Perang Dunia II pada awal pembentukan PBB pada Tahun 1945. HAM dalam pelbagai konteks pemahaman sudah dikenal dan diperjuangkan puluhan bahkan ratusan tahun yang lalu oleh bangsa-bangsa di dunia. Bangsa-bangsa di dunia pada tahun 1948 melalui "Universal Declaration of Human Raights" (UDHR) telah sepakat menyatakan bahwa" setiap manusia dilahirkan merdeka dan sama dalam martabat dan hakhaknya".

HAM berasal dari martabat yang inheren dalam diri manusia, dengan ditegaskan oleh Konvensi PBB mengenai hak sipil dan politik tahun 1966. Hak ini bersifat sangat mendasar, dalam arti pelaksanaannya mutlak diperlukan agar manusia dapat berkembang sesuai dengan bakat, cita-cita serta martabatnya. Hak ini juga dianggap universal artinya dimiliki manusia tanpa perbedaan berdasarkan bangsa, ras, agama atau jenis kelamin.

Secara objektif prinsip perlindungan terhadap HAM antara negara yang satu dengan lainnya adalah sama. Namun 
pelaksanaannya tidaklah demikian. Artinya pada suatu waktu ada persamaan kehendak terhadap apa yang sebaiknya dilindungi dan diatur, namun pada waktu yang lain ada perbedaan persepsi dan penafsiran terhadap HAM antara negara yang satu dengan negara yang lainnya. Perbedaan tersebut lebih banyak disebabkan adanya latar belakang kehidupan yang mencakup ideologi, politik, ekonomi, sosial dan budaya dari masing-masing negara yang tidak sama.

Berkaitan dengan pelaksanaan perlindungan HAM di Indonesia, selama ini Indonesia sering dijadikan "kambing hitam" terutama oleh pihak-pihak Barat. Dalam hal ini tidak sedikit kasus yang ditudingkan negara Barat atau dunia internasional bahwa Indonesia sebagai pelanggar HAM berat, seperti dalam kasus tragedi Semanggi, terbunuhnya Munir yang sampai saat ini belum terungkap, dan yang aktual pembunuhan oleh 11 angota kopasus terhadap 4 tahanan di
Lembaga Pemasyarakatan

Cebongan Kabupaten Sleman DIY. Sehubungan dengan pelanggaran HAM di Indonesia berdasar Laporan Amnesti Internasional tahun ini mencatat masih ada pelanggaran HAM di Indonesia. Dalam Laporan berjudul "The State of the Worlds Human Rights": Indonesia masih melanggar HAM di enam wilayah yaitu penggunaan kekerasan oleh polisi dan tentara; tekanan terhadap kebebasan berekpresi; pelanggaran atas kebebasan beragama; pembatasan hak-hak perempuan dan impunitas serta hukuman mati. Termasuk penyiksaan, penganiayaan lannya, penggunaan senjata dan kekuatan yang berlebihan. Hal ini dikemukakan oleh Sekretaris Jenderal Amnesti Internasional Salil Shetty, dalam laporannya yang dikirim melalui Surat Elektronik (Koran Tempo, tanggal 24 Mei 2013 : A6).

Berdasarkan uraian tersebut di atas dalam era globalisasi bagi negara yang tidak menegakkan 
HAM akan mengalami kesulitan dalam hubungan internasional. Dalam proses globalisasi tidak hanya melanda kehidupan ekonomi, tetapi telah melanda kehidupan yang lain seperti politik, sosial budaya, pertahanan keamanan (hankam), ilmu pengetahuan dan teknologi (iptek), pendidikan dan hukum. Globalisasi di bidang politik antara lain terasa dengan adanya isue tentang lingkungan hidup, transparansi, keterbukaan, demokratisasi dan HAM. Globalisasi semakin memperkuat pemikiran-pemikiran untuk mengoperasionalkan nilainilai dasar HAM yang bersifat universal, invisble and interdependent and interrelated. (Muladi, 1997: 11). Senada dengan Muladi, Hartono (1997: 61) mengemukakan bahwa globalisasi dengan keterbukaannya, telah mengangkat persoalan HAM mejadi persoalan Global, dalam arti pelanggaran terhadap HAM yang terjadi di suatu negara menjadi perhatian dan keprihatinan internasional yang berdampak kepada citra demokratis atau otoritairnya suatu pemerintahan.

Sebenarnya Indonesia sejak menyatakan kemerdekaannya sudah peduli terhadap HAM. Undang-Undang Dasar 1945 yang dibuat sebelum lahirnya Deklarasi Universal tentang HAM tahun 1948, sudah mencantumkan ketentuan-ketentuan yang berkenaan dengan HAM dalam Pembukaan maupun Batang Tubuhnya. Demikian juga dalam kedua UUD yang pernah berlaku di Indonesia yakni UUD RIS (Kontsitusi RIS) dan UUDS juga sudah memasukkan bahasan tentang HAM. Kemudian pada masa orde baru sudah berhasil dibuat pelbagai peraturan perundang-undangan yang mempunyai kaitan dengan pelaksanaan HAM, Lembagalembaga yang dapat menjadi tumpuan dalam pelaksanaan HAM juga sudah dibentuk seperti Komisi Nasional HAM (Komnas) HAM. Kemudian pada era reformasi, telah berhasil 
mengundangkan UU RI Nomor 39 Tahun 1999 tentang Hak Asasi Manusia dan UU RI Nomor 26 Tahun 2000 tentang Pengadilan Hak Aasasi Manusia. Di samping itu empat kali amandemen UUD 1945, banyak memuat pasal mengenai HAM (Pasal 28A s/d Pasal 28J). Namun dalam kenyataannya yang terjadi dalam praktik dewasa ini masih dijumpai bahwa para penyelenggara negara dalam menangani persoalanpersoalan konkret yang terkait dengan HAM masih terdapat kelemahan dan kekurangan, yakni lebih banyak pendekatan kekuasaan (power approach) daripada pendekatan hukum.

Berkaitan dengan masalah HAM di Indonesia tersebut dari dimensi hukum khususnya yang terkait dengan perlindungan HAM di bidang penegakan hukum masih bersifat diskriminatif, sehingga prinsip persamaan di muka hukum tidak terpenuhi, baik dari penyidikan, penuntutan dan peradilan sampai pada tingkat pembinaan narapidana di lembaga pemasayarakatan. (Hartini, 2005: 32). Narapidana seperti halnya manusia pada umumnya mempunyai hak-hak yang juga harus dilindungi oleh hukum. Hakhak yang dilindungi tersebut terutama hak-hak yang sifatnya tidak dapat diingkari dan diganggu gugat oleh siapapun dalam keadaan apapun yakni HAM.

Berkaitan dengan perlindungan HAM terhadap Narapidana di Lembaga Pemasyaraktan ini sebenarnya telah diatur dalam peraturan perundang-undangan. Hal ini dapat diketahui dari UndangUndang Nomor 12 Tahun 1999 tentang Pemasyarakatan, pada Pasal 14 ayat (1), bahwa narapidana berhak: melakukan ibadah sesuai dengan agama atau kepercayaannya, mendapat perawatan rohani maupun jasmani, mendapat pendidikan dan pengajaran, mendapatkan pelayanan kesehatan dan makanan yang layak, menyampaikan keluhan, mendapatkan bahan bacaan dan mengikuti siaran 
media massa lainnya yang tidak dilarang; mendapatkan upah atau premi atas pekerjaan yang dilakukan; menerima kunjungan keluarga, penasehat hukum atau orang tertentu lainnya, mendapatkan remisi; mendapatkan kesempatan berasimilasi termasuk cuti menjelas bebas; dan hak-hak lain sesuai dengan peraturan perundang-undangan yang berlaku.

Perlindungan HAM tersebut juga ditegaskan dalam UndangUndang Nomor 39 Tahun 1999 tentang Hak asasi Manusia, bahwa HAM adalah seperangkat hak yang melekat pada hakikat dan keberadaan manusia sebagai makhluk Tuhan Yang Maha Esa dan merupakan anugerah-Nya yang wajib dihormati, dijunjung tinggi dan dilindungi oleh negara, hukum dan pemerintah, dan setiap orang dalam kehormatan serta perlindungan harkat dan martabat manusia (Pasal 1 angka 1). Di samping itu dalam undang-undang tersebut juga melindungi HAM dan kebebasan dasar Manusia, antara lain: hak untuk hidup, hak untuk berkeluarga, hak untuk mengembangkan diri, hak untuk memperoleh keadilan, hak untuk kebebasan pribadi, hak atas rasa aman, hak turut serta dalam pemerintahan, hak atas kesejahteraan, hak wanita dan hak anak (Pasal 9 s/d Pasal 66).

Namun dalam kenyataan perlindungan HAM terhadap Narapidana di Lembaga Pemasyarakatan belum terpenuhi secara maksimal. Menurut pemberitaan di Media massa masih sering terjadi tindak kekerasan terhadap Narapidana di dalam LAPAS. Hal ini diketahui dari terungkapnya kasus kekerasan berupa pemukulan dan pungutan liar (pungli) di LAPAS Kelas I A Lowokwaru Malang, yang dikemukakan oleh mantan Narapidana Lowokwaru, mengaku mendapat penyiksaan saat di Lapas (Affandi, 2011).

Berita metrotvnews tanggal 15 Maret 2013, ratusan anggota salah satu kelompok ormas 
berunjuk rasa di LAPAS Salemba Jakarta Pusat yang terkait penyerangan kelompok Napi kasus penyerangan di RSPAD terhadap Napi kasus Terorisme di Lapas Salemba(Yudhistira, 2013) Kasus aktual juga terjadi di Lembaga Pemasyarakatan (LAPAS) Cebongan (Sleman) DIY, sebagaimana dikemukakan Siti Noor Laila dari Komnas HAM kepada Rakyat Merdeka "ada indikasi pelanggaran HAM dalam kasus Cebongan pembunuhan oleh 11 anggota kopasus atas 4 tahanan penghuni Sub Anggrek 5 di LAPAS Cebongan. Indikasi pelanggaran HAM atas hak hidup seseorang, hak atas rasa aman, hak perlindungan harta kekayaan, harta benda, nyawanya, hak bebas dari penganiayaan (Prabowo, 2013).

Hasil penelitian pada kajian serupa pada tahun 2014 yang dilakukan oleh Sri Hartini, dkk menunjukkan bahwa perlindungan HAM bagi para narapidana menjadi salah satu sasaran kebijakan Kementerian Hukum dan HAM yang dituangkan dalam berbagai bentuk peraturan perundang-undangan. Kebijakan tersebut dilaksanakan di Lembaga Pemasyarakatan se DIY secara apa adanya. HAM yang dipenuhi di Lapas hanya mengikuti apa yang telah diatur dalam kebijakankebijakan pusat, artinya pihak lapas tidak mengupayakan adanya hak-hak lain. Selain itu, relatif sering terdapat perubahan kebijakan, namun perubahan kebijakan yang dituangkan dalam bentuk peraturan perundangundangan tersebut sifatnya tambal sulam saja. Dengan demikian kebijakan perlindungan HAM terhadap Narapidana di Lapas se DIY menggunakan Model Kebijakan Elite. Namun dalam hal teknis pelaksanaan/pemenuhan HAM Narapidana di Lapas se DIY, pada kenyataannya mengharuskan kreativitas petugas pembina lapas, agar pelaksanaan/pemenuhan hak dapat berjalan dengan baik, yang pada kondisi tertentu berbeda dengan peraturan yang sudah ditetapkan oleh Kementerian 
Hukum dan HAM RI, namun dapat diterima oleh Narapidana. Dalam hal ini sebenarnya kebijakan yang diterapkan juga menggunakan Model Kebijakan Rasional. (Hartini, 2014: 76). Oleh karena itu penting untuk meneliti efektifitas model kebijakan kombinasi (model Kebijakan Elit dan Model Kebijakan Rasional) tentang perlindungan HAM bagi Narapidana di Lapas se DIY.

\section{Tujuan Penelitian}

Tujuan dari penelitian ini adalah untuk memperoleh gambaran mengenai model kebijakan kombinasi perlindungan HAM terhadap narapidana untuk dapat diterapkan di Lembaga Pemasyarakatan se Daerah Istimewa Yogyakarta secara tepat dan berhasil guna.

\section{METODE}

Penelitian ini dilaksanakan di Lembaga Pemasyarakatan Daerah Istimewa Yogyakarta meliputi Lembaga Pemasyarakatan Sleman (Cebongan), Sleman (Pakem), dan
Yogyakarta (Wirogunan). Jenis penelitian ini adalah penelitian diskriptif. Penentuan subjek penelitian/informan ini dengan cara purposive, yakni memilih subjek penelitian/informan secara sengaja oleh peneliti berdasarkan kreteria atau pertimbangan tertentu (Faisal, 1995: 67). Teknik pengumpulan data dengan menggunakan wawancara dan dokumentasi, yang diperkuat dengan FGD. Dalam penelitian ini untuk memeriksa keabsahan data digunakan teknik cross check. Analisis data yang dilakukan dalam penelitian ini adalah analisis induktif yang dilakukan sejak pengumpulan sampai akhir pengumpulan data yang bersifat terbuka. Analisis induktif digunakan untuk menilai dan menganalisis data yang sudah difokuskan pada model kebijakan kombinasi perlindungan HAM terhadap Napi di Lembaga Pemasyarakatan DIY.

\section{HASIL DAN PEMBAHASAN Model Kebijakan}


Perlindungan Hak Asasi Manusia (HAM) sudah menjadi harga mati dalam demokrasi dan sebuah negara hukum. Perlindungan tersebut ditujukan juga terhadap narapidana. Mengingat bahwa narapidana merupakan orang yang sedang menjalani sanksi setelah dinyatakan bersalah, maka hak asasi yang diberikan akan berbeda dengan orang kebanyakan. Namun paradigma pemidanaan era sekarang telah bergeser, yakni pemidanaan lebih berorientasi restoratif, sehingga perlakuan terhadap narapidana juga diarahkan kepada programprogram yang bisa membantu meningkatkan kualitas diri narapidana. Program pembinaan terhadap narapidana dilaksanakan dengan mendasarkan pada kebijakan pemerintah melalui berbagai produk hukum.

Terkait dengan upaya perlindungan HAM narapidana, terdapat suatu kemajuan dalam pengembangan kebijakan. Kepala Divisi Pemasyarakatan Kantor
Wilayah Kementerian Hukum dan HAM Daerah Istimewa Yogyakarta mengungkapkan tentang mulai diterapkannya pembinaan narapidana berbasis HAM. Kebijakan baru ini akan membawa dampak yang signifikan terhadap pemenuhan hak asasi narapidana di Indonesia. Dengan menggunaan pijakan HAM dalam pembinaan narapidana, sebagai konsekuensinya negara harus menyediakan regulasi yang memadai, anggaran yang mencukupi, serta petunjuk teknis yang mampu menjadi guidelines bagi penyelenggara pembinaan narapidana, dalam rangka memastikan hak asasi narapidana terpenuhi; hal-hal inilah yang akan mengarahkan pada bentuk hukum HAM yatiu obligation to fulfill dari negara.

Selama ini kebijakan pembinaan narapidana, khususnya mengenai hak-hak narapidana, seperti Undang-Undang Nomor 12 Tahun 1995 tentang Pemasyarakatan, Peraturan Pemerintah Peraturan Pemerintah 
RI Nomor 31 Tahun 1999 tentang Pembinaan Dan Pembimbingan Warga Binaan Pemasyarakatan, Peraturan Pemerintah RI Nomor 32 Tahun 1999 jo Peraturan Pemerintah RI Nomor 28 Tahun 2006 tentang Perubahan Atas Peraturan Pemerintah No. 32 Tahun 1999 tentang Syarat dan Tata Cara Pelaksanaan Hak Warga Binaan Pemasyarakatan, Peraturan Pemerintah RI No. 99Tahun 2012 tentang Perubahan kedua Atas Peraturan Pemerintah No. 32 Tahun Syarat dan tata Cara Pelaksanaan Hak Warga Binaan Pemasyarakatan dan lain-lain, secara umum telah mengacu dari instrumen SMR atau United Nations Standard Minimum Rules for the Treatment of Prisoners. Instrumen ini merupakan regulasi internasional yang menjadi pedoman negara-negara dalam pemenuhan hak-hak narapidana. Hanya saja dalam tahap implementasi mengalami permasalahan teknis dan kendala sebagaimana terungkap pada hasil penelitian Tahap I Tahun 2014 oleh Sri Hartini, dkk. Permasalahan tersebut antara lain disebabkan karena antara kebijakan satu dengan lainnya tidak saling mendukung. Misalnya permasalahan pemenuhan hak kesehatan yang terjadi akibat kebijakan anggaran yang tidak memadahi, persoalan kewenangan urusan Pemerintah Daerah, juga kebijakan mengenai BPJS yang menyulitkan klaim narapidana dalam mendapatkan bantuan dana kesehatan. Selain itu narapidana tidak mendapatkan premi dari hasil pekerjaannya di dalam lapas karena ada peraturan perundangan yang mengatur keuangan negara yang mengatur bahwa penghasilan yang dihasilkan oleh instansi pemerintah, termasuk lapas, harus masuk ke kas negara sebagai penghasilan negara bukan pajak, sehingga hak narapidana atas upah pekerjaan tidak diperolehnya. Unit pelaksana teknis Lapas lebih "memilih" menerapkan peraturan keuangan negara untuk menghindari dugaan tindak pidana 
korupsi. Jika dicermati permasalahan-permasalahan yang muncul dalam pembinaan narapidana, yang include di dalamnya pemenuhan hak narapidana, disebabkan kebijakan yang dikembangkan lebih menggunakan model elitis di mana pengaruh politik cukup determinan.

Untuk

mengembangkan pembinaan narapidana berbasis HAM, akan lebih efektif dengan menggunakan model kebijakan kombinasi, kombinasi antara kebijakan elit dan kebijakan rasional, seperti yang telah direkomendasikan peneliti pada hasil penelitian tahap I. Model kombinasi kebijakan yang dirancang terkait dengan identifikasi permasalahan dalam perlindungan HAM narapidana.

Hasil penelitian tahap pertama diperoleh model kebijakan kombinasi yaitu kombinas antara model elit dan model rasional dengan permasalahan yang perlu diselesaikan melalui kebijakan kombinasi tersebut antara lain:

1.Tidak tersedianya "Bilik Cinta" untuk narapidana yang sudah menikah;

2. Tidak tersedianya anggaran negara untuk biaya kesehatan narapidana;

3. Belum adanya kelanjutan dari keterampilan yang bisa menciptakan pekerjaan narapidana;

4. Ketidak tersedianya SDM yang profesional dalam bidang pendidikan, agama, kesehatan dan psikologis serta keterampilan;

Hasil rumusan kebijakan kombinasi dibuat Naskah Akademik yang divalidasi dengan ahli hak asasi manusia dan ahli Hukum Pidana dan dilaksanakan FGD untuk mendapatkan Naskah Akademik yang sesuai dengan kondisi riil yang secara keseluruhan dapat diuraikan hasilnya sebagai berikut:

1. Masalah Bilik Cinta dalam Lembaga Pemasyarakatan 
Bilik cinta merupakan suatu upaya untuk memenuhi kebutuhan seksual narapidana dalam rangka mendapatkan hak menjalani hidup secara layak. Namun sejauh ini bilik cinta belum diwujudkan karena dalam peraturan perundangundangan tidak menyebutkan sama sekali mengenai hal ini, sementara pada sisi lain narapidana membutuhkannya. Jika kebutuhan tersebut tidak terpenuhi, maka akan berpotensi pada beberapa perilaku seksual menyimpang, seperti homoseksual, lesbian atau perilaku lainnya. Selain itu akan meningkatkan angka perceraian (ketidakharmonisan keluarga) narapidana.

Kebijakan yang bisa diambil dalam rangka terpenuhinya hak atas kebutuhan biologis ini adalah sebagai berikut:

a. Mengatur "eksistensi" hak atas kebutuhan biologis narapidana di Lapas dalam Undang-Undang (produk legislatif), mengingat pengakuan atas hak-hak narapidana tersebut diatur dalam Undang-Undang Pemasyarakatan, maka sudah seharusnya hak atas kebutuhan biologis narapidana diatur dalam undang-undang. Dalam hal ini perlu ada pembaharuan Undang-Undang Pemasyarakatan yang telah ada, atau dengan kata lain ada perubahan secara tambal sulam. Ini merupakan salah satu cirikhas model kebijakan elit. Hanya saja di sini pembuat kebijakan harus mempunyai perspektif yang luas dan memperhatikan fakta di lapangan.

b. Mengenai pelaksanaan hak atau teknisnya, diatur dalam suatu peraturan menteri. Kebijakan ini dirancang dalam sebuah peraturan menteri dengan memperhatikan pertimbangan rasional dengan menekankan pada 
aspek efektivitas, efisiensi dan ekonomis. Kebijakan ini bertujuan untuk keuntungan sosial yang maksimal. Untuk mencapai efektifitas, efisiensi dalam program "bilik cinta", maka harus diperhatikan aspek-aspek seperti dampak positif, dukungan, kelemahan dan tantangan, sehingga kebijakan yang dihasilkan akan lebih efektif dan efisien. Kebijakan ini merupakan kebijakan rasional.

2. Masalah tidak tersedianya Anggaran Negara untuk biaya kesehatan Narapidana

Tidak tersedianya anggaran/dana kesehatan merupakan bentuk pelanggaran HAM bagi narapidana di lembaga pemasyarakatan untuk memperoleh pelayanan kesehatan. Permasalahan yang muncul dari tidak tersedianya dana kesehatan sangat berkaitan dengan unsur kemanusiaan yang dirasakan bagi narapidana (warga binaan) yang menderita sakit yang serius terutama dari keluarga yang tidak mampu. Berkaitan dengan hal ini setiap narapidana berhak untuk memperoleh pelayanan kesehatan yang layak. Sudah seharusnya setiap lapas disediakan poliklinik beserta fasilitasnya dan disediakan sekurang-kurangnya seorang dokter dan tenaga kesehatan lainnya. Pemeriksaan kesehatan dilakukan paling sedikit 1 kali dalam 1 bulan dicatat dalam kartu kesehatan. Dalam hal napi ada keluhan mengenai keselamatan, maka dokter atau tenaga kesehatan lainnya di Lapas wajib melakukan pemeriksaan. Biaya perawatan kesehatan di rumah sakit bagi penderita dibebankan kepada negara sebagaimana ditegaskan dalam Peraturan Pemerintah No. 32 Tahun 1999 tentang Syarat dan Tata Cara Pelaksanaan Hak Warga Binaan Pemasyarakatan. Namun dalam realita masih terbatas sarana dan prasarana yang menunjang 
perlindungan para narapidana atas kesehatan yang diperolehnya. Di samping itu tidak adanya anggaran untuk obat-obatan bagi narapidana di seluruh lapas di Indonesia. Dari berbagai nara sumber dan dokumen anggaran belanja, pengadaan obat-obatan tidak dianggarkan. Disamping itu adanya pemangkasan anggaran dari pemerintah.

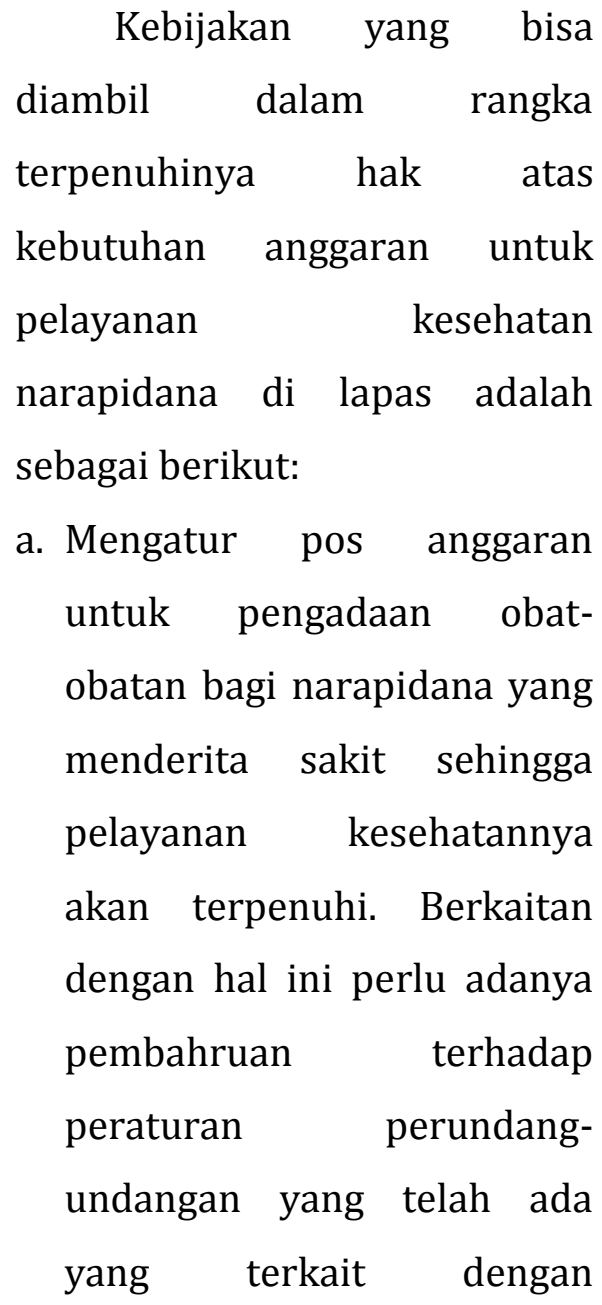

anggaran untuk pelayanan kesehatan bagi narapidana di lapas. Dengan kata lain ada perubahan secara tambal sulam. Ini merupakan salah satu cirikhas model kebijakan elit.

b. Teknis yang diperlukan untuk mengatasi tidak adanya anggaran guna memberikan pelayanan kesehatan bagi narapidana yang dilakukan dengan mengadakan kerja sama antara lembaga pemasyarakatan dengan pihak ketiga atau pihak lain seperti asuransi kesehatan dan pemerintah daerah, sehingga pemenuhan hak atas pelayanan kesehatan narapidana tidak terganggu karena adanya pemangkasan anggaran kesehatan dari pemerintah.

Kebijakan ini dirancang dalam sebuah peraturan menteri dengan memperhatikan pertimbangan rasional 
dengan menekankan pada aspek efektivitas, efisiensi dan ekonomis. Kebijakan ini bertujuan untuk keuntungan sosial yang maksimal. Untuk mencapai efektifitas dan efisiensi. Kebijakan ini termasuk model kebijakan rasional

3. Belum adanya kelanjutan dari keterampilan yang bisa menciptakan pekerjaan narapidana;

Negara bertanggung jawab penuh untuk memenuhi hak narapidana untuk mendapatkan keterampilan dan pelatihan, dengan harapan narapidana setelah bebas akan mempunyai kemandirian secara ekonomi. Dalam pelaksanaan pembinaan keterampilan adanya keterbatasan anggaran serta sumber daya manusia profesional menyebabkan pelaksanaan pembinaan keterampilan menjadi terhambat, terhenti dan alatalat yang digunakan dalam pembinaan keterampilan terbengkalai. Hal ini sanagat tidak efektif dan mengganggu keberlanjutan pembinaan keterampilan bahkan dapat menyebabkan pemborosan dana. Alat-alat pembinaan yang tidak digunakan dan terbengkalai memerlukan biaya tinggi untuk perbaikan jika akan digunakan lagi. Apalagi bila narapidana yang sudah saatnya bebas belum tuntas pembinaan keterampilannya, maka saat kembali kemasyarakat menyebabkan dirinya akan mengalami kesulitan hidup karena tidak memiliki keterampilan yang memadahi yang dapat membantu dirinya untuk survive di masyarakat. Jika kondisi yang demikian terjadi maka menjadi beban masyarakat atas munculnya kejahatan yang dilakukan mantan narapidana.

Kebijakan yang bisa diambil dalam rangka terpenuhinya hak atas kelanjutan dari keterampilan yang bisa menciptakan 
pekerjaan narapidana adalah sebagai berikut:

a. Mengatur mengenai anggaran yang dipergunakan untuk melanjutkan keterampilan dengan melakukan pembaharuan terhadap peraturan yang telah ada sebelumya, yang terkait dengan anggaran untuk pelayanan kesehatan bagi narapidana di lapas. Dengan kata lain ada perubahan secara tambal sulam. Ini merupakan salah satu cirikhas model kebijakan elit.

b. Mengenai teknik yang diperlukan dalam rangka terpenuhinya hak atas kelanjutan dari keterampilan kerjasama antara Lembaga Pemasyarakatan dengan LSM dalam pendirian selter penampungan sementara untuk melakukan pembinaan keterampilan kepada narapidana. Kebijakan ini dirancang dalam sebuah peraturan menteri dengan memperhatikan

pertimbangan rasional dengan menekankan pada aspek efektivitas, efisiensi dan ekonomis. Kebijakan ini bertujuan untuk keuntungan sosial yang maksimal. Untuk mencapai efektifitas dan efisiensi. Kebijakan ini termasuk model kebijakan rasional

4. Ketidaktersedianya SDM yang profesional dalam bidang pendidikan, agama, kesehatan dan psikologis serta keterampilan;

Ketidak tersedianya SDM yang profesional dalam bidang pendidikan, agama, kesehatan dan psikologis serta keterampilan di Lapas se DIY, mengakibatkan kurang adanya kemandirian dari Lapas dalam menjalankan tugas pokok dan fungsinya (tupoksi). Tidak tersedianya SDM profesional sesuai bidangnya yang memadahi menjadikan pembinaan kepada narapidanan di Lapas se DIY kurang 
maksimal. Hal ini memaksa lapas melibatkan SDM yang dimiliki untuk menjalankan tugas pembinaan dengan kemampuan secara amatir. Hal ini kurang menjamin dimilikinya keterampilan yang maksimal bagi narapidana sebagai bekal setelah bebas mejalani masa pidananya.

Kebijakan yang bisa diambil dalam rangka terpenuhinya SDM yang profesional dalam bidang pendidikan, agama, kesehatan dan psikologi serta keterampilan yang bisa menciptakan pekerjaan narapidana adalah sebagai berikut:

a. Mengatur tentang pengadaan SDM yang profesional dalam bidang pendidikan, agama, kesehatan dan psikologi serta keterampilan dengan melakukan pembaharuan terhadap peraturan yang telah ada sebelumya. Dengan kata lain ada perubahan secara tambal sulam. Ini merupakan salah satu cirikhas model kebijakan elit.

b. Mengenai teknik yang diperlukan dalam rangka terpenuhinya SDM yang profesional dalam bidang pendidikan, agama, kesehatan dan psikologi serta keterampilan yang dilakukan oleh petugas lapas yakni kreativitas dalam menjalankan tugasnya dengan menjalin kerjasama antara Lembaga Pemasyarakatan dengan LSM baik dengan pemerintah daerah maupun LSM untuk melakukan pembinaan bidang pendidikan, agama, dan keterampilan kepada narapidana. Kebijakan ini dirancang dalam sebuah peraturan menteri dengan memperhatikan pertimbangan rasional dengan menekankan pada aspek efektivitas, efisiensi dan ekonomis. Kebijakan ini bertujuan untuk keuntungan sosial yang maksimal untuk 
mencapai efektifitas dan

efisiensi. Kebijakan ini termasuk model kebijakan rasional.

\section{Efektifitas Pelaksanaan Model}

\section{Kebijakan Kombinasi}

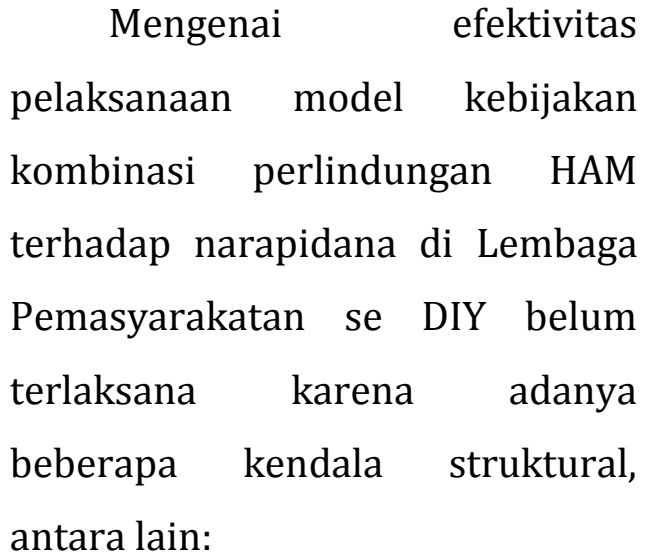

1. Sistem kewenangan pengambil kebijakan di Pemerintahan yang sentralistik.

Secara struktur organisatoris/institusi atau kelembagaan, Lembaga Pemasyarakatan se DIY hanya sebagai Unit Pelaksana Teknis (UPT) di bawah koordinasi Kantor Wilayah Kementerian Hukum dan HAM DIY. Di samping itu Kantor Wilayah Kementerian Hukum dan HAM merupakan instansi vertikal, sehingga dalam pelaksanaan tugasnya mengikuti kebijakan dari pusat yaitu Kementerian Hukum dan HAM.

2. Untuk melaksanakan uji coba model kebijakan kombinasi, akan berimplikasi pada banyak aspek yaitu struktur organisasi, narapidana yang jumlahnya besar dan anggaran yang digunakan untuk keperluan penyediaan fasilitas pendukung pelaksanaan.

3. Lokasi tempat uji coba kebijakan sangat bersifat politis

Kebijakan itu sangat tergantung pada kemauan politik (political wiil) pengambil kebijakan beserta kelompoknya

\section{SIMPULAN}

Dari hasil dan pembahasan penelitian tentang model kebijakan kombinasi perlindungan HAM terhadap narapidana di Lembaga Pemasyarakatan se DIY dapat dikemukakan kesimpulan sebagai berikut:

1. Model kebijakan kombinasi perlindungan HAM terhadap Narapidana dapat digambarkan 
sesuai permasalahan riil, antara lain:

a.Tidak tersedianya "Bilik Cinta" untuk narapidana yang sudah menikah.

Kebijakan yang bisa diambil dalam rangka terpenuhinya hak atas kebutuhan biologis ini adalah sebagai berikut :

1) Mengatur "eksistensi" hak atas kebutuhan biologis narapidana di Lapas dalam Undang-Undang (produk legislatif), mengingat pengakuan atas hak-hak narapidana tersebut diatur dalam UndangUndang Pemasyarakatan, maka sudah seharusnya hak atas kebutuhan biologis narapidana diatur dalam undang-undang. Dalam hal ini perlu ada pembaharuan UndangUndang Pemasyarakatan yang telah ada, atau dengan kata lain ada perubahan secara tambal sulam. Ini merupakan salah satu cirikhas model kebijakan elit. Hanya saja di sini pembuat kebijakan harus mempunyai perspektif yang luas dan memperhatikan fakta di lapangan.

2) Mengenai pelaksanaan hak atau teknisnya, diatur dalam suatu peraturan menteri. Kebijakan ini dirancang dalam sebuah peraturan menteri dengan memperhatikan pertimbangan rasional dengan menekankan pada aspek efektivitas, efisiensi dan ekonomis. Kebijakan ini bertujuan untuk keuntungan sosial yang maksimal. Untuk mencapai efektifitas, efisiensi dalam program "bilik cinta", maka harus diperhatikan aspek-aspek seperti dampak positif, dukungan, kelemahan dan tantangan, sehingga kebijakan yang dihasilkan akan lebih efektif dan efisien. Kebijakan ini 
merupakan kebijakan

rasional

b. Masalah tidak tersedianya Anggaran Negara untuk biaya kesehatan Narapidana

Kebijakan yang bisa diambil dalam rangka terpenuhinya hak atas kebutuhan anggaran untuk pelayanan kesehatan narapidana di lapas adalah sebagai berikut :

1)Mengatur pos anggaran untuk pengadaan obatobatan bagi narapidana yang menderita sakit sehingga pelayanan kesehatannya akan terpenuhi. Berkaitan dengan hal ini perlu adanya pembahruan terhadap peraturan perundang-undangan yang telah ada yang terkait dengan anggaran untuk pelayanan kesehatan bagi narapidana di lapas. Dengan kata lain ada perubahan secara tambal sulam. Ini merupakan salah satu cirikhas model kebijakan elit.

2) Teknis yang diperlukan untuk mengatasi tidak adanya anggaran guna memberikan pelayanan kesehatan bagi narapidana yang dilakukan dengan mengadakan kerja sama antara lembaga pemasyarakatan dengan pihak ketiga atau pihak lain seperti asuransi kesehatan dan pemerintah daerah, sehingga pemenuhan hak atas pelayanan kesehatan narapidana tidak terganggu karena adanya pemangkasan anggaran kesehatan dari pemerintah.

$$
\text { Kebijakan ini }
$$

dirancang dalam sebuah peraturan menteri dengan memperhatikan

pertimbangan rasional dengan menekankan pada aspek efektivitas, efisiensi dan ekonomis. Kebijakan ini 


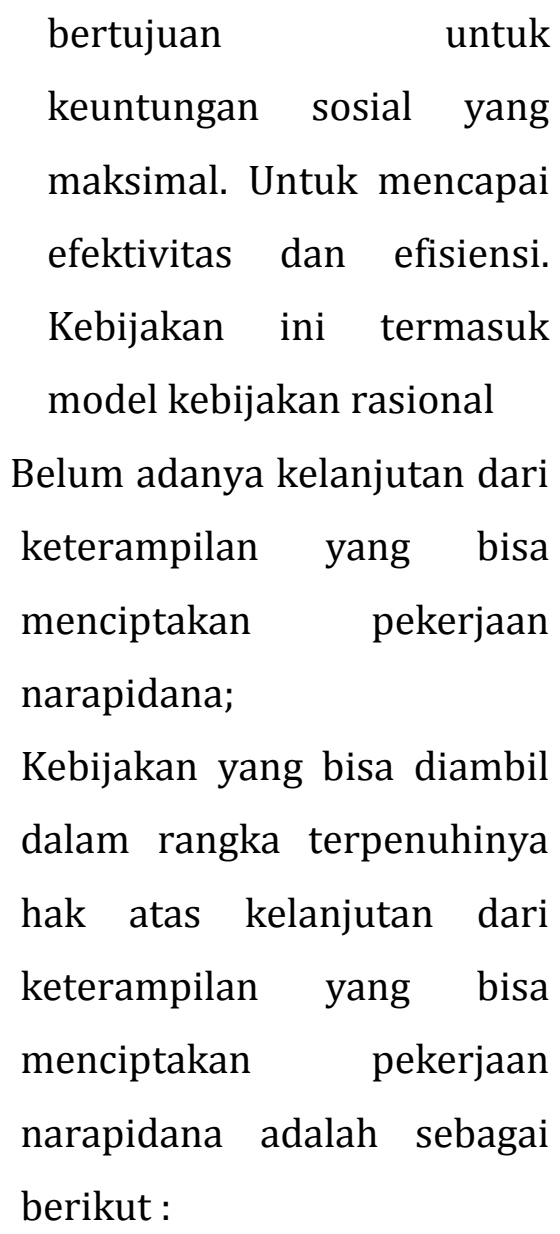

1) Mengatur mengenai anggaran yang dipergunakan untuk melanjutkan keterampilan dengan melakukan pembaharuan terhadap peraturan yang telah ada sebelumya. yang terkait dengan anggaran untuk pelayanan kesehatan bagi narapidana di lapas. Dengan kata lain ada perubahan secara tambal sulam. Ini merupakan salah satu cirikhas model kebijakan elit.

2) Mengenai teknik yang diperlukan dalam rangka terpenuhinya hak atas kelanjutan dari keterampilan kerjasama antara Lembaga Pemasyarakatan dengan LSM dalam pendirian selter penampungan sementara untuk melakukan pembinaan keterampilan kepada narapidana. Kebijakan ini dirancang dalam sebuah peraturan menteri dengan memperhatikan pertimbangan rasional dengan menekankan pada aspek efektivitas, efisiensi dan ekonomis. Kebijakan ini bertujuan untuk keuntungan sosial yang maksimal. Untuk mencapai efektifitas dan efisiensi. Kebijakan ini termasuk model kebijakan rasional 
d. Ketidak tersedianya SDM yang profesional dalam bidang pendidikan, agama, kesehatan dan psikologis serta keterampilan.

Kebijakan yang bisa diambil dalam rangka terpenuhinya SDM yang profesional dalam bidang pendidikan, agama, kesehatan dan psikologi serta keterampilan yang bisa menciptakan pekerjaan narapidana adalah sebagai berikut :

1) Mengatur tentang pengadaan SDM yang profesional dalam bidang pendidikan, agama, kesehatan dan psikologi serta keterampilan dengan melakukan pembaharuan terhadap peraturan yang telah ada sebelumya. Dengan kata lain ada perubahan secara tambal sulam. Ini merupakan salah satu cirikhas model kebijakan elit.
2) Mengenai teknik yang diperlukan dalam rangka terpenuhinya SDM yang profesional dalam bidang pendidikan, agama, kesehatan dan psikologi serta keterampilan yang dilakukan oleh petugas lapas yakni kreativitas dalam menjalankan tugasnya dengan menjalin kerjasama antara Lembaga Pemasyarakatan dengan LSM baik dengan pemerintah daerah maupun LSM untuk melakukan pembinaan bidang pendidikan, agama, dan keterampilan kepada narapidana. Kebijakan ini dirancang dalam sebuah peraturan menteri dengan memperhatikan pertimbangan rasional dengan menekankan pada aspek efektivitas, efisiensi dan ekonomis. Kebijakan ini bertujuan 
untuk keuntungan sosial yang maksimal. Untuk mencapai efektifitas dan efisiensi. Kebijakan ini termasuk model kebijakan rasional

2. Efektifitas Pelaksanaan Model Kebijakan Kombinasi

Mengenai efektivitas
pelaksanaan model kebijakan
kombinasi perlindungan HAM
terhadap narapidana di
Lembaga Pemasyarakatan se
DIY belum terlaksana karena
adanya beberapa kendala
struktural, antara lain:

a. Sistem kewenangan pengambil kebijakan di Pemerintahan yang sentralistik.

Secara struktur organisatoris/institusi atau kelembagaan, Lembaga Pemasyarakatan se DIY hanya sebagai Unit Pelaksana Teknis (UPT) di bawah koordinasi Kantor Wilayah Kementerian Hukum dan HAM DIY. Di samping itu Kantor Wilayah Kementerian
Hukum dan HAM merupakan instansi vertikal, sehingga dalam pelaksanaan tugasnya mengikuti kebijakan dari pusat yaitu Kementerian Hukum dan HAM.

b. Untuk melaksanakan uji coba model kebijakan kombinasi, akan berimplikasi pada banyak aspek yaitu struktur organisasi, narapidana yang jumlahnya besar dan anggaran yang digunakan untuk keperluan penyediaan fasilitas pendukung pelaksanaan.

c. Lokasi tempat uji coba kebijakan sangat bersifat politis; Kebijakan itu sangat tergantung pada kemauan politik (political wiil) pengambil kebijakan beserta kelompoknya

\section{UCAPAN TERIMA KASIH}

Tim Peneliti mengucapkan terima kasih kepada :

1. Rektor UNY dan jajarannya, Dekan beserta pengelola Fakultas Ilmu Sosial UNY dan LPPM UNY yang telah 
memfasilitasi

perolehan

dana/finansial untuk penelitian

ini melalui penyelenggaraan

kompetisi dana penelitan

melalui skim penelitian Hibah

Bersaing serta dukungan lain

sehingga penelitian ini berjalan lancar.

2. Kepala Kantor Wilayah Kementerian Hukum dan HAM

DIY c.q Kepala Devisi Pemasyarakatan yang telah memberikan ijin untuk melakukan penelitian di Lembaga Pemasyarakatan se DIY, menyediakan tempat pelaksanaan focus group discussion (FGD) dan juga telah memberikan data penelitian yang dibutuhkan;

3. Prof. Dr.Marcus Priyo gunarto, S.H; M.Hum sebagai pakar ahli hukum pidana dari Fakultas hukum UGM atas validasinya terhadap usulan naskah akademik Rancangan Kebijakan Perlindungan HAM terhadap Narapidana di lapas se DIY

4. Eko Riyadi, S.H; M.H sebagai pakar ahli HAM dari Pusat
Kajian HAM UII Yogyakarta atas validasinya untuk penyempurnaan Usulan Naskah Akademik Rancangan Kebijakan Perlindungan HAM terhadap Narapidana di lapas se DIY

5. Kepala Lembaga Pemasyarakatan Kelas IIA Yogyakarta (Wirogunan), Kepala Lembaga Pemasyarakatan Kelas IIB Sleman (Cebongan), Kepala Lembaga Pemasyarakatan Narkotika Kelas IIA Yogyakarta (Pakem) dalam hal ini Bagian seksi Pembinaan Pemasyarakatan, yang telah memberikan masukan dalam kegiatan focus group discussion (FGD) sebagai salah satu teknik pengumpulan data penelitian.

6. Beberapa Petugas Lembaga Pemasyarakatan Kelas IIA Yogyakarta, Kelas IIB Sleman dan Lembaga Pemasyarakatan Narkotika Kelas IIA Yogyakarta yang telah mengikuti focus group discussion (FGD).

7. Semua rekan (dosen dan admin) di Jurusan PKNH atas semua 
dukungan dalam rangka pelaksanaan penelitian ini.

8. Semua pihak yang tidak dapat disebutkan satu per satu yang telah membantu dan mendukung terselesaikannya penelitian ini.

\section{DAFTAR PUSTAKA}

Afandi, A.S. 2011. "Mantan Napi Lowokwaru Mengaku Mendapat Penyiksaan Saat di Lapas.

http://mediacenter.malangk ota.go.id/tay/kekerasan-pdnapi/8/6-2011. diunduh 24 April 2013.

Hartini, Sri. 2005. "Perlindungan HAM dalam Praktek Ketatanegaraan Di Indonesia dalam Era Globalisasi”. Jurnal Civics. Vol 2, No. 1.

Hartini, Sri, dkk. 2014. Hasil penelitian Tahap I tentang Kebijakan Perlindungan HAM terhadap Narapidana di Lembaga Pemasyarakatan Se Daerah Istimewa Yogyakarta. Yogyakarta: LPPM UNY.

Hartono, Dimyati. 1997. Lima Langkah Membangun
Pemerintahan Yang Baik. Jakrta: In Hill Co. 16 Muladi. 1997. Hak Asasi Manusia, Politik dan Sistem Peradilan Pidana. Semarang: UNDIP for Prison Officials. New York and Geneva: United Nation.

Prabowo, Dani. 2013. "Komnas HAM: Ada Indikasi Pelanggaran HAM dalam Kasus Cebongan”, http/www.rmol.co/read/201 3/04/16/106575/Siti-NoorLaila: Ada-pelanggaran-HAMdalam kasus cebongan. diunduh 26 April 2013.

Undang-undang Nomor 39 Tahun 1999 tentang Hak Aasasi Manusia.

Undang-Undang Nomor 12 Tahun 1995 tentang

Pemasyarakatan.

Yudhistira, Andri. 2013. "Napi Kasus Terorisme Dianiaya, Ormas Datangi LP Salemba" http/www.metrotvnews.com /metronew/video/2013/03/ 15/6/173270/napi-kasusterorisme- dianiaya, diunduh 26 April 2013. 